\title{
The effect of fiscal deficit on economic growth in an emerging economy: Evidence from Vietnam
}

\author{
Le Thanh Tung \\ Faculty of Economics and Public Management, Ho Chi Minh City Open \\ University, Ho Chi Minh City, Vietnam \\ tung.lt@ou.edu.vn
}

Abstract. Fiscal deficit has been sharply increasing in the developing economies worldwide. This paper examines the effect of fiscal deficit on economic growth in Vietnam, the country now is one of the most dynamically emerging countries, but its government has been facing large fiscal deficits for many years by now. Our study has applied the Error Correction model on the quarterly data of 20032016. The empirical results strongly indicate there is a cointegration relationship between fiscal deficit and economic growth in Vietnam, in which fiscal deficit had harmful effects on economic growth in both short and long run. In particular, the correlation analysis has confirmed that fiscal deficit can hurt not only the gross output but also private investments, foreign direct investments, and net exports. Our results provide evidence for policymakers, and not only in Vietnam but also in other emerging countries which are in need of urgent solutions so that to reduce the fiscal deficit rate and have more sustainable growth in the future.

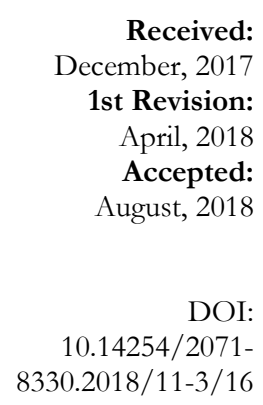

Received:

December, 2017

1st Revision:

April, 2018

Accepted:

August, 2018

DOI:

$10.14254 / 2071$ $8330.2018 / 11-3 / 16$

Keywords: fiscal deficit, economic growth, private investment, foreign direct investment, net exports, emerging economies, CIVETS, Vietnam.

JEL Classification: E61, E62, H61, H62

\section{INTRODUCTION}

Since the 1980s Vietnamese government has started its economic revolution (named 'Doi Moi') in order to transform the centrally-planned economy into the market one. At the beginning of this revolution (1986), Vietnam was one of the poorest countries in the world and the data from the Vietnam General Statistics Office (GSO) showed that the agriculture sector had the largest share $(38.06 \%)$ in gross domestic product (GDP), the second largest was the service's sector with $33.06 \%$ and the smallest sector was the industry with $28.88 \%$ of GDP (GSO, 2017). In 2016, the structure of Vietnamese economy was already seriously changed with the largest sector of services being $40.92 \%$ of GDP, the second largest was the industrial sector with $32.72 \%$, the agricultural sector had only $16.32 \%$ (GSO, 2017). Over the last decades, Vietnam has been considered to be a rather successful example of such transition among developing countries worldwide. According to the statistics from the World Bank, in 2016, Vietnam's economy was 
ranked $14^{\text {th }}$ in Asia and 47th in the world with its GDP reaching $\$ 202.6$ billion and its economic growth rate being about 5.6\% (World Bank, 2017). Although the Vietnamese economy is still strongly dependent on the exports of oil, natural resources as well as foreign direct investment, the country has also evaluated its potential internal resources for further economic growth. Nowadays, Vietnam is recognized as one of the fastest growing countries in Asia. In particular, according to the ranking report by the Economist Intelligence Unit (EIU) back in 2009, Vietnam was mentioned as a member of the group of emerging markets named 'CIVETS' (the group of the fastest growing countries formed by Colombia, Indonesia, Vietnam, Egypt, Turkey and South Africa). The CIVETS was forecasted to have an important role as a new motivation for the world economic growth in the next decades (McGregor, 2011).

However, the Vietnamese economy began facing some problems in the recent years, e.g., its economic growth rate slowed down, while the inflation quickly increased. The average rate of economic growth was $8.2 \%$ per year in 2003-2007, then it dropped to 5.8\% per year in the period from 2008 to 2013 (GSO, 2017). One of the most dangerous factors for the Vietnamese economy is the fiscal deficit in this country which is getting only higher. Although the government has taken great efforts to reduce its expenditures on the state companies as well as its system by means of privatization, these processes have been rather slow and for now have demonstrated quite low efficient results. The fiscal deficit of this country remains to be at the level of approximately $5 \%$ of GDP. This becomes a great risk for the stability of the Vietnamese economy in the long run. According to the Vietnamese Ministry of Finance (MOF), in 2003, the fiscal deficit was only VND 30,500 billion (approximately $\$ 1.9$ billion), it increased to VND 48,613 billion (approximately $\$ 3.02$ billion) in 2006 and then reached VND 114,442 billion (approximately $\$ 6.04$ billion) in 2010. At the end of the 2016 fiscal year, the deficit of Vietnam's government reached VND 192,000 billion (approximately $\$ 8.4$ billion), and this is 6.3 times higher as compared to the 2003 level (MOF, 2017).

Fiscal deficit is not a problem of Vietnam's economy only, in fact, this is a common problem for the majority of developing countries. According to the World Bank's statistics, fiscal deficit has been increasing in most of emerging and developing economies worldwide. Although many of these economies have strengthened their policies and accumulated significant savings over the past two decades, they still could not fully solve their fiscal problems and balance their situation. In the emerging countries, the average deficit continuously rose from around 1\% of GDP back in 2007 to around 5\% of GDP in 2016 (Kose et al., 2017). Although this deficit is continuously increasing in the emerging countries worldwide, the effect of fiscal deficit on economic growth in this group of countries still lacks empirical evidence. And the available research results on this topic provide rather contradictory conclusions. Thus, there was some evidence showing a negative impact of fiscal deficit on economic growth (Cebula, 1995; Ghura, 1995; Biza et al., 2015; Arjomand et al., 2016), however, other researchers have concluded it has a positive impact (Ahmad, 2013) or an insignificant one (Radman, 2012; Velnampy and Achchuthan, 2013).

Reviewing the literature, we have seen that there is hardly any evidence on the fiscal deficit impacts for the case of Vietnam. In a rare investigation, Van and Sudhipongpracha (2015) analysed the impacts of budget deficit on the economic performance of Vietnamese economy in the period 1989-2011, however, their result confirmed that there was no relationship between budget deficit and economic growth. However, can we really believe that the fluctuation of the fiscal deficit does not have any effect on growth in Vietnam? Can we state that the increase in government spending has no impact on the growth of the economy? The answers to these and other related questions can be very useful for many policymakers, and not only Vietnam but also in the developing world overall. In this paper, we have employed the Error correction model and the Johansen test to analyse the model which is comparable with the result offered by Van and Sudhipongpracha (2015). Our findings are expected to provide answers to the following two questions: (i) Is there any cointegration relationship between fiscal deficit and economic growth in Vietnam? (ii) Does the fiscal deficit harm (negative relationship) economic growth in Vietnam in the short run and in 
the long run? Finally, the paper also suggests some policy implications on how to decrease the deficit and promote economic growth along with more sustainability for Vietnam in the near future already.

The paper consists of five sections. Section 2 reviews both theoretical and empirical literature on the relationship between budget deficit and economic growth. Section 3 describes the methodology and the data. The empirical results and discussion are presented in Section 4. Finally, Section 5 provides conclusions and some policy implications.

\section{LITERATURE REVIEW}

The real impact of the fiscal deficit on economic growth is one of the most argued issues among economists and policymakers in both developing and developed countries worldwide in the recent decades. As we discussed, the investigated results did not unite in the same way in the literature of the effect of fiscal deficit on growth. There were some empirical studies which focused on fiscal deficit issue and its effect on economic growth, however, the literature review had got some kinds of the evidence including negative, positive effect or non-effect on this relationship.

Firstly, there were some studies showed that the fiscal deficit had a negative impact on economic growth in both developing and developed countries. Freidman (1963) told when the economy was facing the budget deficit, its government must be made some solutions to solve this situation. However, each measure was implemented to offset the deficit which creates certain consequences for the economy. In particular, according to monetary theory, if the first measure was implemented through the government by issuing of cash, which would increase both the money supply and inflation. On the other hand, when fiscal policy and monetary policy were tightening to reduce inflation, they simultaneous constrained economic growth. Karras (1994) investigated the budget deficit issue in a sample of 32 countries with annual data in 1950-1989. Although the result showed that the deficits had a negative effect on the rate of growth of real output (economic growth) in these countries, however, the author concluded that this reverse relationship occurs within the same year, it was inappropriate to interpret it as a causal relationship from budget deficit to the growth. The result might imply the governments were run deficits in years of slow economic growth than during expansionary times.

Cebula (1995) studied the effect of the budget deficit on the growth of the US's economy with quarterly data in the period 1955-1992. The study result showed that the deficit had been reducing the economic growth rate. The results also confirmed that the personal income tax had a harmful impact on the growth of the economy. Accordingly, the results implied when the budget deficit increased which led to an increase in tax ratio to generate additional revenues for compensating the deficit in the previous period, however, that way also have been restricting the economic growth. Ghura (1995) investigated the effects of macroeconomic policies on nominal income growth, inflation, and output growth. The author used the data collected from 33 countries in Sub-Saharan Africa in 1970-1987. The result explored that the increase in the budget deficit ratio had an adverse effect on output growth in the countries in the research period.

Fatima et al. (2012) conducted a study in Pakistan for the period 1978-2009. The study result also pointed out the budget deficit had a negatively impact on economic growth. Augustt et al. (2015) focused on the causal relationship between the fiscal deficit and output fluctuations in Ghana with time series data from 1960-2012. The empirical result showed a two-way causality relationship between the fiscal deficit and the output in this country. Kameda (2014) analyses the relationship between budget deficits and some macros factors in the Japanese economy. The estimation result found that the real budget deficit in Japan in 2008 caused an approximately $0.39-0.63 \%$ decrease in the real GDP in this year. Hassan et al. (2104) analysed the relationship between deficit spending of the US's government and GDP with the time series data collected from the economy. The result revealed that the deficit in government spending had a negative 
impact on the national output. They found that only unemployment had a negative effect on the output in the presence of deficit spending. The result also pointed out that there had got a cointegration in the longterm relationship between the unemployment rate, interest rate, inflation rate and GDP.

In a rare research in Vietnam, Van and Sudhipongpracha (2015) studied the effects of the budget deficit and economic performance in the Vietnamese economy in the period 1989-2011. However, the result concluded that the government deficits have no direct effects on the country's economic productivity and the economic growth. Their findings also showed that the foreign direct investment played an important role in support the economic productivity (and growth) in Vietnam in the study period. Biza et al. (2015) done an investigative study about the effect of budget deficit on private investment in South Africa with quarterly data in 1994-2009. The study applied the cointegration and vector auto-regression technique to provide the long run and short run dynamic effects on private investment. The empirical result found that budget deficit significantly crowds out private investment in the long-run. The finding also indicated a negative impact of the budget deficit on growth because the decreasing of investment led to a slowdown in the long-term growth.

Arjomand et al. (2016) tried to study the effect of growth, efficiency and government budget deficit in MENA selected countries in the period of 2000-2013 by using the recommended static panel models. The results indicated government budget deficit which is the dependent variable indicate positive effects on economic growth and inflation rate variables. However, the public deficit also has a negative effect on labour productivity. Moreover, the regression in which economic growth is the dependent variable demonstrated the positive impact of labor productivity index and economic growth. Navaratnam and Mayandy (2016) examined the effect of fiscal deficit on economic growth in five South Asian countries (including Bangladesh, India, Nepal, Pakistan and Sri Lanka) with annual data over the period 1980-2014. The study result confirmed that the fiscal deficit has a negative impact on economic growth in Bangladesh, India, Pakistan and Sri Lanka, however, the evidence in Nepal was a positive impact in this period.

Secondly, there were some empirical studies found some contrastive results which suggested a positive effect or non-effect of the fiscal deficit on the economic growth in the economies. Radman (2012) investigated the deficit issue in the case in Malaysia with the quarterly data in 2000-2011. The result showed that there was no long-term relationship between fiscal deficit and economic growth of Malaysia. Velnampy and Achchuthan (2013) had a study which found out the effect of fiscal deficit on economic growth in Sri Lankan with the data in1970-2010. However, the authors did not find the existence of the relationship between the fiscal deficit on economic growth in this country. Ahmad (2013) used the data in Pakistan in the period of 1971-2007 to test the relationship among the fiscal deficit on GDP. The result indicated a positive relation, however, it was insignificant statistics in the case of Pakistan. Pelagidis and Desli (2014) discussed the potential of fiscal policy in supporting growth with some European experiences. The authors argued that budget deficit maybe led to higher business profits, therefore, supporting the economic growth. The result suggested an evidence pointing to a positive relationship between fiscal deficit and capital profitability. This evidence also implied that the dogmatic aversion to budget deficits may be dangerous.

\section{METHODOLOGY AND DATA}

\subsection{METHODOLOGY}

The estimated strategy of our paper has three steps, first one is the testing of unit roots and the cointegrating test between variables. Secondly, the regression of the gross product function by the Ordinary least squares (OLS) technique to identify the effect of fiscal deficit on economic growth in Vietnam in the long run. In the third step, we will use the Error correction model (Engle and Granger, 1987) to analyse the 
effect of fiscal deficit on short-term economic growth in the economy. According to the literature of econometrics, the Error correction model is a commonly econometric methodology which applies to the time series data. The method also special match in the case that is the variables in the function have a longrun stochastic trend, we usually define as cointegration phenomenon. The Error correction model is a quantitative approach which can be used for estimating both short-term and long-term impacts of a time series variable on another. We can understand that the term error correction as the information related to the fact that adjusted deviation from a long-run equilibrium and the error influence its short-run dynamics. So the Error correction model is a useful method that can directly estimate the speed at which a dependent variable returns to equilibrium after a change in other variables in the function.

In order to analyse the effect of fiscal deficit on economic growth in the long run, we take an econometric function which presented in the following equation:

$$
\mathrm{GDP}_{\mathrm{t}}=\beta_{0}+\beta_{1} \mathrm{PINV}_{\mathrm{t}}+\beta_{2} \mathrm{FDI}_{\mathrm{t}}+\beta_{3} \mathrm{FD}_{\mathrm{t}}+\beta_{4} \mathrm{EX}_{\mathrm{t}}+\mathrm{u}_{\mathrm{t}}
$$

Where GDP denotes Gross domestic product, PINV is Private investment, FDI presents Foreign direct investment, FD denotes Fiscal deficit, NX is Net exports (We define by Export minus Import values) and $\mathrm{u}$ is error term.

We employ the Johansen (1988) method in order to test the cointegration relationship between variables in equation (1). The Johansen method could be used to calculate two likelihood ratio criteria (including the Maximum Eigenvalue and Trace statistics) to test the number of cointegration vectors in the model. The likelihood ratio values are respectively calculated as the following functions:

$$
\begin{array}{ll}
\lambda_{\text {Maximum }}=-\mathrm{T} \ln \left(1-\lambda_{\mathrm{r}+1}\right) & \mathrm{r}=0,1,2, \ldots, \mathrm{p}-1 \\
\lambda_{\text {Trace }}=-\mathrm{T} \sum_{\mathrm{r}+1}^{\mathrm{p}} \ln \left(1-\lambda_{\mathrm{i}}\right) & \mathrm{r}=0,1,2, \ldots, \mathrm{p}-1
\end{array}
$$

According to the Johansen (1988) method, we have $\mathrm{T}$ is the sample size and $\lambda_{\mathrm{i}}\left(\mathrm{i}=1,2, \ldots, \mathrm{p} ; \lambda_{1}>\lambda_{2}\right.$ $\left.>\ldots>\lambda_{\mathrm{p}}\right)$ is called as the Eigenvalue. The $\lambda_{\text {Maximum }}$ statistic checks the null hypothesis $\left(\mathrm{H}_{0}\right)$ of $\mathrm{r}$ cointegrating against the alternative hypothesis $\left(\mathrm{H}_{1}\right)$ that there are $(\mathrm{r}+1)$ cointegrating vectors. In the $\lambda_{\text {Maximum }}$ test, the null hypotheses to be tested are in a checking procedure of the following: $\mathrm{H}_{0}: r=0$ against $\mathrm{H}_{1}: \mathrm{r}=1 ; \mathrm{H}_{0}: \mathrm{r}$ $\leq 1$ against $\mathrm{H}_{1}: \mathrm{r}=2 ; \ldots ; \mathrm{H}_{0}: \mathrm{r} \leq \mathrm{p}-1$ against $\mathrm{H}_{1}: \mathrm{r}=\mathrm{p}$. We can have an example, if $\mathrm{H}_{0}: \mathrm{r}=0$ is rejected at $95 \%$ based on the critical value and $\mathrm{H}_{0}: \mathrm{r} \leq 1, \ldots$ and $\mathrm{H}_{0}: \mathrm{r} \leq \mathrm{p}-1$ are all not rejected at the same value, then we conclude that the $\lambda_{\text {Maximum }}$ test statistic indicates the existence of at most one cointegrating vector. Then we have the $\lambda_{\text {Trace }}$ statistic also checks the null hypothesis $\left(\mathrm{H}_{0)}\right.$ that has at most $\mathrm{r}$ co-integrating vectors in the equation. The testing result implies the number of co-integrating vectors is less than or equal to $\mathrm{r}$. In the case of the $\lambda_{\text {Trace }}$ statistic, the null hypotheses to be tested are in a checking procedure including $\mathrm{H}_{0}: \mathrm{r}=0$ against $\mathrm{H}_{1}: \mathrm{r} \geq 1 ; \mathrm{H}_{0}: \mathrm{r} \leq 1$ against $\mathrm{H}_{1}: \mathrm{r} \geq 2 ; \ldots ; \mathrm{H}_{0}: \mathrm{r} \leq \mathrm{p}-1$ against $\mathrm{H}_{1}: \mathrm{r}=\mathrm{p}$. For example, we have $\mathrm{H}_{0}: \mathrm{r}$ $=0$ is rejected at $95 \%$ based on the critical value and $\mathrm{H}_{0}: \mathrm{r} \leq 1, \ldots$ and $\mathrm{H}_{0}: \mathrm{r} \leq \mathrm{p}-1$ can not be rejected at the same value, the $\lambda_{\text {Trace }}$ test concludes the existence of at least one cointegrating vector.

After the Johansen testing result confirms the existence of at least one cointegrating vector between the variables in the function. We will estimate the equation (1) by the Ordinary least squares (OLS) technique in order to explore the long-term relationship between fiscal deficit and economic growth. Next step, based on the long-term regression result, we will assign $u_{t}=E C_{t}$. Following the Engle and Granger (1987) method, we denote ECT which represented the Error correction term that is calculated as follows: 


$$
\mathrm{ECT}_{\mathrm{t}}=\mathrm{GDP}_{\mathrm{t}}-\beta_{0}-\beta_{1} \mathrm{PINV}_{\mathrm{t}}-\beta_{2} \mathrm{FDI}_{\mathrm{t}}-\beta_{3} \mathrm{FD}_{\mathrm{t}}-\beta_{4} \mathrm{EX}_{\mathrm{t}}
$$

Subsequently, the effect of fiscal deficit on economic growth in the short run is defined by the following equation:

$$
\Delta \mathrm{GDP}_{\mathrm{t}}=\delta_{0}+\delta_{1} \Delta \mathrm{PINV}_{\mathrm{t}}+\delta_{2} \Delta \mathrm{FDI}_{\mathrm{t}}+\delta_{3} \Delta \mathrm{FD}_{\mathrm{t}}+\delta_{4} \Delta \mathrm{EX}_{\mathrm{t}}+\delta_{5} \mathrm{ECT}_{\mathrm{t}-1}+\varepsilon_{\mathrm{t}}
$$

The coefficient of Error correction term $\left(\delta_{5}\right)$ is used to measure the speed of adjustment back from the short-term to the long-term equilibrium. In the equation (5), we use the symbol ' $\Delta$ ' to denote the first difference value of the time series in the function.

\subsection{DATA DESCRIPTION}

Unlike previous studies in Vietnam, our paper uses the quarterly data over the period from the first quarter of 2003 to the fourth quarter of 2016 with a sample including 56 observations. Excepting fiscal deficit is collected from the Ministry of Finance of Vietnam, all of the data are sourced from the Vietnam General Statistics Office. Besides, the values of variables are calculated at the current price (nominal value) and the unit of variables is VND trillion. The descriptive statistics of the variables are shown in the following table.

Table 1

Descriptive statistics of the variables

\begin{tabular}{|l|c|c|c|c|c|}
\hline Statistic & GDP & PINV & FDI & FD & NX \\
\hline Mean & 482.3374 & 72.87679 & 45.15714 & -27.84977 & -247.6530 \\
\hline Median & 366.0235 & 71.00000 & 51.85000 & -18.94850 & -213.8465 \\
\hline Maximum & 1377.772 & 192.0000 & 109.1000 & -1.545000 & 1715.175 \\
\hline Minimum & 95.78700 & 13.50000 & 5.900000 & -73.21000 & -1269.105 \\
\hline Std. Dev. & 348.3192 & 47.83470 & 26.66749 & 21.24259 & 462.5856 \\
\hline Skewness & 0.991183 & 0.565651 & 0.134325 & -0.583895 & 0.810805 \\
\hline Kurtosis & 3.015992 & 2.412437 & 2.232900 & 2.109828 & 7.617752 \\
\hline Jarque-Bera & 9.170080 & 3.791837 & 1.541433 & 5.030987 & 55.89092 \\
\hline Probability & 0.010203 & 0.150180 & 0.462681 & 0.080823 & 0.000000 \\
\hline Observations & 56 & 56 & 56 & 56 & 56 \\
\hline
\end{tabular}

Source: Author calculated from research data. ${ }^{*} \mathrm{GDP}$ is Gross domestic product, PINV is Private investment, FDI is Foreign direct investment, FD is Fiscal deficit, NX is Net exports. Unit: VND trillion.

\section{EMPIRICAL RESULTS AND DISCUSSION}

\subsection{TESTING FOR UNIT ROOT AND COINTEGRATION}

Following the literature of statistics, we can define a unit root (also spoken a unit root process or a difference stationary process) is a stochastic trend in a time series or sometimes called as 'a random walk with drift'. In the case, if a time series has a unit root or non-stationary, it shows a systematic pattern that is unpredictable. Stock and Watson (1988) had noted that some usual testings of statistics (eg, t, F or R²) cannot have the standard distributions if some of the time series in the equation have unit roots. So we must use the unit root test is testing for stationary in a time series before estimating the econometric function. 
In order to test the unit root of the variables such as Gross domestic product (GDP), Private investment (PINV), Foreign direct investment (FDI), Fiscal deficit (FD) and Net exports (NX), this paper employs the Augmented Dickey-Fuller (ADF) testing method. We decided to choose ADF test because this method allows for the less restrictive assumptions for the time series in the function than others. We have used the conditions including (1) with intercept, (2) with trend and intercept, and (3) without constant for the technique. However, the testing results show that there is only the NX is stationary at a significance level of $1 \%$ with trend and intercept as well as 5\% with intercept and without constant model. The remaining variables (including GDP, PINV, FDI, and FD) are not stationary with three testing models. Besides, the unit root test with the first difference values confirmed that all of the variables are stationary at the significance of $1 \%$. The results suggest there maybe has the existence of the cointegration relationship at the level I(1) among variables in the econometric equation. The unit root test results are presented in the below table.

Result of Unit root test of the variables

\begin{tabular}{|l|c|c|c|}
\hline In level & With intercept & $\begin{array}{c}\text { With trend and } \\
\text { intercept }\end{array}$ & $\begin{array}{c}\text { Without } \\
\text { constant }\end{array}$ \\
\hline Variable & 2.266010 & -1.012503 & 5.081547 \\
\hline Gross domestic product (GDP) & 0.373910 & -3.151819 & 2.950115 \\
\hline Private investment (PINV) & 0.327195 & -1.976790 & 2.702966 \\
\hline Foreign direct investment (FDI) & -0.718158 & -2.457535 & 0.972147 \\
\hline Fiscal deficit (FD) & $-3.232270^{* *}$ & $-6.217485^{* * *}$ & $-2.526406^{* *}$ \\
\hline Net exports $(\mathrm{NX})$ & \multicolumn{3}{|l|}{} \\
\hline In first difference & With intercept & With trend and & Without \\
\hline Variable & $-10.22458^{* * *}$ & $-11.23808^{* * *}$ & $-2.936261^{* * *}$ \\
\hline$\Delta$ Gross domestic product $(\Delta \mathrm{GDP})$ & $-14.16569^{* * *}$ & $-14.13585^{* * *}$ & $-12.66680^{* * *}$ \\
\hline$\Delta$ Private investment $(\Delta \mathrm{PINV})$ & $-9.271328^{* * *}$ & $-9.259091^{* * *}$ & $-8.179279^{* * *}$ \\
\hline$\Delta$ Foreign direct investment $(\Delta \mathrm{FDI})$ & $-13.70426^{* * *}$ & $-13.56101^{* * *}$ & $-13.42223^{* * *}$ \\
\hline$\Delta$ Fiscal deficit $(\Delta \mathrm{FD})$ & $-13.66423^{* * *}$ & $-13.52686^{* * *}$ & $-13.79733^{* * *}$ \\
\hline$\Delta$ Net exports $(\Delta \mathrm{NX})$ & & & constant \\
\hline
\end{tabular}

Source: Author calculated from research data. * indicates significance level at 0.10 level, ** indicates significance level at 0.05 level, *** indicates significance level at 0.01 level.

Continuously, we endeavor to test the null of no cointegration as opposed to the alternative hypothesis. The Johansen test (1988) is employed to examine all the possible cointegration relationship among the variables in the function. According to the testing results based on Johansen (1988) method, we can reject the null hypothesis $\left(\mathrm{H}_{0}\right)$ that there is no cointegrating vector in the long run. The results (Table 3 ) indicate that the null hypothesis of no cointegration vector between the variables is rejected at $5 \%$ level of significance. In particular, both Trace test and Maximum-Eigenvalue test results also confirm the existence of at most two cointegration vectors among the variables at the 5\% significant level. The results imply that there is a long-term relationship between gross domestic product (GDP), private investment (PINV), foreign direct investment (FDI), fiscal deficit (FD) and net exports (NX) in Vietnam. The results of the Johansen test are summarized in Table 3. 
Result of Johansen cointegration test

\begin{tabular}{|l|c|c|}
\hline The hypothesis $\mathbf{H}_{\mathbf{0}}$ & Trace statistic test & Max-Eigen test \\
\hline There is no cointegration equation* & $103.4753(69.818)$ & $46.7973(33.8768)$ \\
\hline There is a cointegration equation in maximum* & $56.6780(47.8561)$ & $33.6227(27.5843)$ \\
\hline There are 2 cointegration equations in maximum & $23.0553(29.7970)$ & $17.6778(21.1316)$ \\
\hline There are 3 cointegration equations in maximum & $5.3774(15.4947)$ & $5.0068(14.2646)$ \\
\hline
\end{tabular}

Source: Author calculated from research data.* denotes rejection of the null hypothesis at the $1 \%$ level of significance and the critical values are in parentheses.

\subsection{CORRELATION ANALYSIS}

The correlation testing is one of the most simple methods, however, it's really useful statistics to analyse the relationships in a matrix of variables. According to the literature of the econometrics, we see that a correlation is a single number that describes the degree of relationship between two variables. Our correlation results show the correlation coefficients between amongst of the variables in our econometric equation. There are a number of issues which discovering through this correlation analysis. The correlation values between amongst variables are reported in the next table.

Table 4

Correlation matrix results

\begin{tabular}{|l|c|c|c|c|c|}
\hline Variables & GDP & PINV & FDI & FD & NX \\
\hline GDP & 1.000000 & & & & \\
\hline PINV & 0.885898 & 1.000000 & & & \\
\hline FDI & 0.884865 & 0.830101 & 1.000000 & & \\
\hline FD & $\mathbf{- 0 . 7 2 4 8 5 3}$ & $\mathbf{- 0 . 7 1 6 2 8 8}$ & $\mathbf{- 0 . 5 9 4 3 8 8}$ & 1.000000 & \\
\hline NX & 0.280860 & 0.202579 & 0.120202 & $\mathbf{- 0 . 1 0 3 7 9 2}$ & 1.000000 \\
\hline
\end{tabular}

Source: Author calculated from research data.

The correlation matrix has some highlighted points which need some discussions. Firstly, the most important result in the matrix maybe is the sign of the value of gross domestic product (GDP) and fiscal deficit (FD). We can see that there is a negative sign (-0.724853) which implies a negative relationship between two variables. Based on the result, we can fastly forecast that fiscal deficit will lead to decreasing of the economic growth in Vietnam. Secondly, we can see that fiscal deficit can hurt the investment flows in the economy. Thus, the result also shows that fiscal deficit has negative relationships with both private investment (-0.716288) and foreign direct investment (-0.594388) because of the negative sign of the correlative values. Thirdly, fiscal deficit also has a negative relationship with net exports $(-0.103792)$ which leads to a thinking that the increase of fiscal deficit will drive a decrease in the trade balance of the economy.

According to the correlation results, we can be agreed that fiscal deficit is really a difficult problem that must be handled as soon as possible by the Vietnamese government to have a sustainable development in the future. Based on the result, we also have fairly understood about the harmful effects of fiscal deficit on not only gross domestic product (or economic growth) but also some important macro sectors in Vietnam. The evidence has provided a good note for the policymakers must have some urgent solutions to solve this problem in Vietnam. Finally, the result indicates that the gross domestic product has the positively correlated with a number variables, including private investment (PINV), foreign direct investment (FDI) and the net exports (NX) in Vietnam in the study period. 


\subsection{REGRESSION RESULTS}

The result of Johansen test (1988) has confirmed the existence of at least one long-term cointegration relationship among such variables as the gross domestic product, private investment, foreign direct investment and net exports in the Vietnamese economy. Therefore, in this section, we will estimate the equation (1) to identify the coefficients which exactly describe the long-term relationships between gross domestic product and among variables. However, in many cases of statistical analysis, we are not sure whether our regression result is correctly specified. One solution to the problem is to test whether our results are consistent with the estimated assumptions. Therefore, in order to check the serial correlation phenomenon, we applied the LM Breusch-Godfrey method, however, we found the serial correlation at $\mathrm{AR}(1)$ in the regression result. We have employed the Cochrane-Orcutt procedure to solve the serial correlation of the statistical sample. Finally, the diagnostic tests have done but the testing results confirmed that the estimation result is free of the serial autocorrelation, the heteroskedasticity phenomenon as well as the normal distributions. The estimated result in the long run and the diagnostic tests are described in the below table.

Estimation result of the long-term model

\begin{tabular}{|c|c|c|}
\hline \multicolumn{3}{|c|}{ Dependent Variable: Gross domestic product } \\
\hline Variables & Coefficient & t-statistic \\
\hline Constant & -17.32531 & -0.876816 \\
\hline Private investment & $1.371722^{* * *}$ & 3.452243 \\
\hline Foreign direct investment & $7.809968^{* * *}$ & 8.698868 \\
\hline Fiscal deficit & $-3.341696 * * *$ & -4.788074 \\
\hline Net exports & $0.043249^{*}$ & 1.783138 \\
\hline R-squared & \multicolumn{2}{|l|}{0.778409} \\
\hline \multicolumn{3}{|l|}{ Model diagnostics } \\
\hline \multicolumn{3}{|c|}{ Serial Correlation test (LM Breusch-Godfrey) $=0.255895[0.7753]$} \\
\hline \multicolumn{3}{|c|}{ Heteroskedasticity test (White) $=0.728139[0.7341]$} \\
\hline \multicolumn{3}{|c|}{ Normality test $($ Jarque-Bera) $=0.613264[0.735921]$} \\
\hline
\end{tabular}

Source: Author calculated from research data.* indicates significance level at 0.10 level, ** indicates significance level at 0.05 level, $* * *$ indicates significance level at 0.01 level. We have used the CochraneOrcutt procedure to solve the serial correlation at $\operatorname{AR}(1)$.

Firstly, we will focus on the most important coefficient in the regression result. The most highlighted point on the table maybe is the sign of fiscal deficit's coefficient. The estimation result shows that fiscal deficit (FD) has a negative relationship with GDP in the long run at the significant level of $1 \%$. The effect is very clear because of the high value of the coefficient. This finding is contrary to the previous study done by Van and Sudhipongpracha (2015) which concluded that there was no relationship between budget deficit and economic growth in Vietnam's economy. However, our result is especially in line with that of some empirical studies in both developed and developing countries (Cebula, 1995; Ghura, 1995; Fatima et al., 2012; Biza et al., 2015; Arjomand et al., 2016). This result also implies that fiscal deficit has a harmful effect on economic growth in the long run in Vietnam. We can discuss further more about this finding because it is consistent with some evidence in Vietnam in recent years. After a long period of rapid economic growth, the Vietnamese economy was facing some challenges which include the decline of economic growth and macroeconomic instability in the years. Our result is supported by the current evidence of the Vietnamese 
economy in this period. In particular, from economic growth to reach 7.0\% average in 1995-2000 and 7.5\% in the period 2001-2007, the average growth rate has dropped to 5.5\% in 2008-2012. The growth was only recovered to $6.03 \%$ per year in the period 2013-2016 (GSO, 2017). Also during there periods, besides the number of corporate bankruptcies increased and the output decline has increased, we saw that the deficit of fiscal years has been moving fastly with many worried comments from the policymakers in Vietnam. So based on this empirical result, we can conclude that the increase of fiscal deficit will lead to a decrease in long-term economic growth in the case of Vietnam.

Our regression results continuously confirmed that all of three variables including private investment (PINV), foreign direct investment (FDI) and net exports (NX) had a positive impact on economic growth in Vietnam in long run. The value of R-square presents that $77.84 \%$ of the proportion of total variations of gross domestic product is explained by independent variables included in the long-term model. As we have discussed in the Introduction of the paper, the economic and political reforms under 'Doi Moi' had been beginning a long period of rapid growth in Vietnam. The Vietnamese government also strongly encouraged the people to have their business and supported the development of the private sector in the market. Besides, the policymakers took some extensive reforms to built a multi-sectoral economy based on different types of ownership, encouraging for foreign investments and foreign trade between Vietnam and the partnerships worldwide. The estimated result contributed more empirical to the literature of economic growth in the developing world. The findings are supported by previous studies about the economic growth in Vietnam as well as developing countries, which indicate the positive relationship between growth and private investment (eg, Adams, 2009; Chotia and Rao, 2017), and foreign direct investment (eg, Borensztein et al., 1998; Basu and Guariglia, 2007; Adams, 2009; Chotia and Rao, 2017) and international trade (eg, Akayleh, 2014). However, based on the comparison of coefficient values, we can agree that the foreign direct investment plays a very important role in supporting the growth in Vietnam. This conclusion also united with the evidence of Van and Sudhipongpracha (2015) for the role of foreign direct investment in Vietnam.

In this part, we will employ the Error correction model to identify the effect of fiscal deficit on economic growth in Vietnam in the short run. According to the reference from Engle and Granger (1987), firstly, the values of variables will be calculated from the level to the first difference. As the regression strategy, secondly, we use the error correction terms (ECT) which are the error-term values in the equation (1). Besides analysing the relationships between variables, we see another purpose of the error correction term of the model is to indicate the speed of adjustment from the short-term to the long-term equilibrium state. The estimated results of short-term coefficients and diagnostic tests are presented in Table 6. By the testing values in the table, we can conclude that the estimated results continuously pass the diagnostic tests including the serial autocorrelation, the heteroskedasticity phenomenon as well as the normal distributions.

Based on the quantitative procedure, firstly, we can see that the short-term estimated result unites with the result in the long-run. The short-term estimation confirmed the fiscal deficit continuously has a negative relationship with the economy's output (as well as economic growth) at the $1 \%$ level of significance. The coefficient values implied that fiscal deficit caused economic growth slowdown in not only the short run but also the long run. The result also identified that the harmful effect of the fiscal deficit to Vietnam's output in the short run (-2.865001) is smaller than in the long run (-3.341696). 
Estimation result of the short-term model

\begin{tabular}{|l|c|c|}
\hline Dependent Variable: $\Delta$ Gross domestic product \\
\hline Variables & Coefficient & t-statistic \\
\hline Constant & 3.147099 & 0.290466 \\
\hline$\Delta$ Private investment & $1.371125^{* * *}$ & 4.161315 \\
\hline$\Delta$ Foreign direct investment & $7.232473^{* * *}$ & 7.332239 \\
\hline$\Delta$ Fiscal deficit & $-2.865001^{* * *}$ & -4.756454 \\
\hline$\Delta$ Net exports & $0.033880^{*}$ & 1.692464 \\
\hline ECT(-1) & $-0.285147^{* * *}$ & -2.880253 \\
\hline R-squared & 0.668591 & \\
\hline $\begin{array}{l}\text { Model diagnostics } \\
\text { Serial Correlation test (LM Breusch-Godfrey test) }=1.384509[0.2605] \\
\text { Heteroskedasticity test (White test) }=0.743526[0.7554] \\
\text { Normality test (Jarque-Bera test) }=0.247133[0.883763]\end{array}$ \\
\hline
\end{tabular}

Source: Author calculated from research data.* indicates significance level at 0.10 level, ** indicates significance level at 0.05 level, *** indicates significance level at 0.01 level.

This evidence could be explained because of the fiscal policy's operational lag, which is the period of time between the point at that a policy or procedure is implemented and the point when it starts to take effect in the economy. Both private investment and foreign direct investment were found to have positive relationships with the gross domestic product in the short run at the significance of $1 \%$ level. The evidence highly reflects that two kinds of investment are the most important resources in promoting economic growth in Vietnam during the study period. The net exports continuously showed a positive impact on growth at the significance of $10 \%$ level, however, its small estimated coefficients indicated that these impacts were quite weak in both long run and short run. Finally, the coefficient of the Error correction term equal to -0.285147 (significance at 1\% level) implied a correct sign, which measures the speed of adjustment back from the short-term to the long-term equilibrium. The result also indicated that speed of adjustment is quite slow from the short-term to the long-term equilibrium.

\section{CONCLUSION AND POLICY IMPLICATION}

The fiscal deficit is a complex problem that many countries are facing and solving this macro trouble. As a result of expansionary fiscal policies to the economy, the fiscal deficit also has been sharply increasing in emerging markets and developing economies. Vietnam is one of the fastest growth in the world during three decades so the evidence from this economy is very useful references for others (especially in the group of emerging countries, eg the CIVEST). Our study applied the Error Correction model and Johansen test to deeply analysis the effects of fiscal deficit on economic growth in Vietnam, a highlighted country which have a record in the field of growth in developing countries in previous time. We collected a quarterly database in 2003-2016 with 56 observations to use for the study.

Based on the quantitative methodologies, our results clearly showed that the fiscal deficit had a negative effect on economic growth in Vietnam not only the short run but also in the long run. Moreover, the correlation analysis also pointed out that fiscal deficit also has a harmful effect on some macro variables in the econometric model including private investment, foreign direct investment as well as net exports. Our investigated result is a strong evidence for policymakers not only in Vietnam but also emerging countries should have some urgent solutions to fastly slowdown the rate of the deficit in order to have a sustainable 
growth in the coming time. The result confirmed that fiscal deficit can hurt not only output but also some important macro sectors including investment flows and net exports. Besides, our result continuously confirmed that the private investment, foreign direct investment, and international trade have very important roles in promoting the economic growth in Vietnam. Finally, the study result has contributed some investigated references to the theoretical framework about the relationship of fiscal deficit and macroeconomic issues in the case of Vietnam, a highlighted developing country in the world.

Our result also suggests that the policymakers in Vietnam need to make the higher effort to reduce its expenditure, example, to the state companies by the equitizing strategy to exchange them to the private sector, so the public budget does not spend to maintain a large the state-owned sector because the government expenditure for this sector is one of the important causes of the prolonged deficit. Besides, the Vietnamese government may try to generate more revenue from domestic fees and taxes, which focus on the household' expenditure for the luxuries products and services from foreign countries. Our result also implies that the Vietnamese government need try some hard solutions to decrease its employees in the public system (to cut the public wage funding) by the applying more and more information technology (automatic technology) in the offices. The decrease of wage expenditure in the public sector will help to cut the deficit in the future.

\section{REFERENCES}

Adams, S. (2009). Foreign Direct investment, domestic investment, and economic growth in Sub-Saharan Africa. Journal of Policy Modeling, 31(6), 939-949. https://doi.org/10.1016/j.jpolmod.2009.03.003

Akayleh, F. A. (2014). Impact of trade openness on economic growth in a small, open, and developing economy: new instrumental variables for trade openness. International Journal of Sustainable Economy, 6(2), 142-170. https://doi.org/10.1504/IJSE.2014.060346

Ahmad, N. (2013). The Role of Budget Deficit in the Economic Growth of Pakistan. Global Journal of Management and Business Research Economics and Commerce, 13(5), 1-4.

Arjomanda, M., Emamib, K., \& Salimic, F. (2016). Growth and Productivity; the role of budget deficit in the MENA selected countries. Procedia Economics and Finance, 36, 345-352. https://doi.org/10.1016/S2212-5671(16)30046-6

Augustt, R. M., Adu, G., \& Frimpong, P. B. (2015). The nexus between output fluctuations and fiscal deficits: empirical evidence on Ghana. International Journal of Sustainable Economy, 7(2), 100-117. https://doi.org/10.1504/IJSE.2015.068676

Basu, P., \& Guariglia, A. (2007). Foreign Direct investment, inequality, and growth. Journal of Macroeconomics, 29, 824839. https://doi.org/10.1016/i.jmacro.2006.02.004

Biza, R. A., Kapingura, F. M., \& Tsegaye, A. (2015). Do budget deficits crowd out private investment? An analysis of the South African economy. International Journal of Economic Policy in Emerging Economies, 8(1), 52-76. https://doi.org/10.1504/IJEPEE.2015.068248

Borensztein, E., Gregorio, J., \& Lee, J-W. (1998). How does foreign direct investment affect economic growth?. Journal of International Economics, 45, 115-135. https:// doi.org/10.1016/S0022-1996(97)00033-0

Cebula, R. J. (1995). The impact of Federal government budget deficit on economic growth in the United States: An empirical investigation, 1955-1992. International Review of Economics and Finance, 4(3), 245-252. https://doi.org/10.1016/1059-0560(95)90042-X

Chotia, V., \& Rao, N. V. M. (2017). Examining the impact of public investment and private investment on economic growth: empirical evidence from BRICS nations. International Journal of Economics and Business Research, 14(2), 128137. https://doi.org/10.1504/IJEBR.2017.10007792

Engle, R. F., \& Granger, C. W. J. (1987). Co-integration and error correction: Representation, estimation and testing. Econometrica, 55(2), 251-276. https://doi.org/10.2307/1913236

Fatima, G., Ahmed, M., \& Rehman, W. U. (2012). Consequential effects of budget deficit on economic growth of Pakistan. International Journal of Business and Social Science, 3(7), 203-208.

Friedman, M. (1963). Inflation: Causes and Consequences. New York: Asia Publishing House, USA. 
Johansen, S. (1988). Statistical Analysis of Cointegration Vectors. Journal of Economic Dynamics and Control, 12(2-3), 231254. https://doi.org/10.1016/0165-1889(88)90041-3

Kose, A., Ohnsorge, F., \& Sugawara, N. (2017). Rising debt and deficits in Emerging Market and Developing Economies (EMDEs) in 5 charts. The World Bank [online] http://blogs.worldbank.org/developmenttalk/rising-debt-anddeficits-emerging-market-and-developing-economies-emdes-5-charts. (accessed August, 20, 2017)

Ghura, D. (1995). Effects of macroeconomic policies on income growth, inflation, and output growth in Sub-Saharan Africa. Journal of Policy Modeling, 17 (4), 367-395. https://doi.org/10.1016/0161-8938(94)00037-G.

GSO. (2017). Statistics (National accounts) database. Retrieved from http://www.gso.gov.vn/Default_en.aspx?

tabid $=766$ (accessed June, 25, 2017)

Hassan, M., Nassar, R., \& Liu, C. (2014). Effect of Government deficit spending on the GDP in the United States. Journal of Economic and Economic Education Research, 15(3), 103-112.

Karras, G. (1994). Macroeconomic effects of budget deficits: further international evidence. Journal of International Money and Finance, 13(2), 190-210. https://doi.org/10.1016/0261-5606(94)90015-9

Kameda, K. (2014). 'Budget deficits, government debt, and long-term interest rates in Japan. Journal of the Japanese and International Economies, 32, 105-124. https://doi.org/10.1016/j.jjie.2014.02.001.

McGregor, H. (2011). Jim O’Neill Game Changer. Brunswick Review, 4, 27-29.

Navaratnam, R., \& Mayandy, K. (2016). Causal nexus between fiscal deficit and economic growth: Empirical evidence from South Asia. International Journal of Innovation Education and Research, 4(8), 1-19.

MOF. (2017). Statistics database. Retrieved from http://www.mof.gov.vn/webcenter/portal/mof/r/k/statis? (accessed July, 16, 2017)

Pelagidis, T., \& Desli, E. (2014). Deficits, growth, and the current slowdown: what role for fiscal policy?. Journal of Post Keynesian Economics, 26(3), 461-469.

Phillips, P. C. B., \& Perron, P. (1988). Testing for a Unit Root in Time Series Regression. Biometrika, 75(2), 335-346. https://doi.org/10.2307/2336182

Rahman, N. H. A. (2012). The relationship between Budget deficit and Economic growth from Malaysia's perspective: An ARDL Approach, International Conference on Economics. Business innovation IPEDR, 38, 54-58.

Sowa, N. K. (1994). Fiscal deficits, output growth and inflation targets in Ghana. World Development, 22(8), 1105-1117. https://doi.org/10.1016/0305-750X(94)90079-5

Stock, J. H., \& Watson, M. W. (1988). Testing for common trends. Journal of the American Statistical Association, 83, $1097-$ 1107.

Van, V. B., \& Sudhipongpracha, T. (2015). Exploring Government budget deficit and Economic growth: Evidence from Vietnam's economic miracle. Asian Affairs: An American Review, 42, 127-148. doi. https://doi.org/10.1080/00927678.2015.1048629

Velnampy, T., \& Achchuthan, S. (2013). Fiscal deficit and Economic growth: A study in Sri Lankan economic perspective. Developing Country Studies, 3(3), 166-174.

World Bank. (2017). World Development Indicators. Retrieved from https://data.worldbank.org/indicator/NY.GDP.MKTP.CD?year_high_desc=true (accessed July, 26, 2017). 